\title{
Methodologically blonde at the UN in a tactical quest for inclusion
}

\section{Halme-Tuomisaari, Miia Marika}

2018-11

Halme-Tuomisaari , M M 2018 , ' Methodologically blonde at the UN in a tactical quest for inclusion ' , Social Anthropology, vol. 26 , no. 4 , pp. 456-470 . https://doi.org/10.1111/1469-8676.12583

http://hdl.handle.net/10138/325825

https://doi.org/10.1111/1469-8676.12583

unspecified

acceptedVersion

Downloaded from Helda, University of Helsinki institutional repository.

This is an electronic reprint of the original article.

This reprint may differ from the original in pagination and typographic detail.

Please cite the original version. 
Methodologically blonde at the UN in a tactical quest for inclusion

Miia Halme-Tuomisaari (University of Helsinki)

Forthcoming in Social anthropology / Anthropologie Sociale, November 2018 (8000 words)

Abstract

How can anthropologists negotiate access in high profile, bureaucratic apparatuses, such as a UN human rights monitoring mechanism - and what can a detailed account of these negotiations tell us of such apparatuses, their operational dynamics, and the processes via which they exert an impact, broadly construed? This paper addresses these questions via the notion of tactical subjectivity by anchoring its discussion on the category of the intern and detailing how this category became informative of the 'fuzzy logic' of the UN apparatus. The article outlines three techniques mobilized in the process - name-dropping, 'playing blonde' and opportunism-all embedded in a tactical matrix of exaggerated transparency. This article further shares attempts to flesh out relations and thus form 'liaisons' between my interlocutors and myself at sessions of the UN Human Rights Committee, the most influential of all the UN treaty bodies overseeing how states comply with their covenant-bound obligations. The ultimate aim was become a conspicuous ethnographer with constant access - a volatile goal in the unpredictable microstructures of this awesome global apparatus.

KEYWORDS: United Nations, human rights treaty body, apparatus, methodology, conspicuous ethnographer

How can anthropologists negotiate access to high profile bureaucratic apparatuses, such as a UN human rights monitoring mechanism, and get their interlocutors to engage with their projects? What can a detailed account of such negotiations tell us of these apparatuses, their inner contours, operational dynamics and the processes via which they exert an impact, broadly construed, in and on the world? This article addresses these issues by focusing on the micro-processes of access in three sessions of the UN Human Rights Committee, the treaty body that monitors how states comply with the obligations they have undertaken by becoming parties to the International 
Covenant on Civil and Political Rights (ICCPR), commonly called the most authoritative of all UN human rights monitoring mechanisms. ${ }^{1}$

Building on Greg Feldman's analysis of the anthropological study of global processes and 'persistent empirical anxiety' (Feldman 2011), this article conceptualizes its target of investigation as a formidable human rights 'apparatus' characterized by mediated relations and direct social connections. Foucault has described the apparatus, aka dispositif, as a 'heterogenous ensemble consisting of discourses, institutions, architectural forms, regulatory decisions, laws, administrative measures, scientific statements, philosophical, moral and philanthropic propositions-in short, the said as much as the unsaid' (Foucault 1977; see also Rabinow 2003, 50-54; Feldman 2011, 380). ${ }^{2}$ These elements resonate with the human rights apparatus, further characterized as entailing three partially overlapping, partly autonomous elements: the human rights discourse(s), artefacts and community (Halme-Tuomisaari 2010).

Further, the human rights apparatus can somewhat paradoxically be seen as both spaceless and multilocal, as well as having distinct 'centres' and 'peripheries' marked either by fixed locations or passing conglomerations of action and expertise (Wallerstein 2004, Halme-Tuomisaari 2017). The UN Human Rights Committee is an undoubted a centre on both accounts; its sessions are accompanied by the gathering of leading human rights experts from around the world, accompanied by state representatives and NGO delegates. They are held in Geneva, the European headquarters of the UN - increasingly the organization's international human rights capital - at the beautiful Palais Wilson, the former headquarters of the League of Nations and today the home of the UN Office of the High Commissioner for Human

\footnotetext{
${ }^{1}$ This paper has benefitted from generous funding by the Academy of Finland project 'Human Rights: Religion, Law, Subjectivity' (2009-2012); the Max Planck Institute for Social Anthropology (Halle/Saale), Department of Law \& Anthropology; the University of Turku; and the Kone Foundation. Warm thanks to Julie Billaud, Greg Feldman, Isabelle Schulte-Tenckhoff and Jane Cowan for helpful comments on different drafts of this paper, as well as three anonymous reviewers, Theodoros Kyriakides and Sarah Green for editorial comments. Warm thanks to Marie-Louise Karttunen for expert language editing on an impossible schedule.

2 See also Foucault 1980, 194-228; and Callewaert 2007, 29-52.
} 
Rights (UNOHCHR 2018). ${ }^{3}$ Yet, despite the fixed geographic nature, it would be erroneous to treat the Committee's sessions as loci for straightforward participant observation as the "the global is not just local writ large,... a web of direct connections multiplied for the world stage', but rather involves 'qualitatively different forms of organizing society' (Feldman 2011, 378).

This article engages with these observations by addressing issues of access embodied in attempts to navigate the amorphous border of inclusion beyond the evident point of collecting one's badge at the UN accreditations office and proceeding through the security gates. The article describes the UN apparatus through the metaphor of ice, casting the sessions of the Human Rights Committee as the tip of a formidable iceberg (Cowan \& Billaud 2017). Further, it discusses the inner dynamics guiding processes of inclusion and exclusion via the notion of 'fuzzy logic'. The phrase is borrowed from Bourdieu who utilized it to underline the exaggeratedly rigid nature of such analytical concepts as 'system', or 'structure' by emphasizing the indeterminacy of the rules that diverse agents mobilize in practice, as well as the creative gap between 'habitus and institutional structure' (Bourdieu 1992: 62-63, see also Bourdieu 1977, 81-2; and Friedland 2009, 4).

This article discusses how 'fuzzy logic' interacts with the ideal of transparency in UN operations, showing how, ironically, often the policies implemented to ensure transparency rather cloud it over, as in the case of producing 'truthful' human rights documents (Billaud 2014), resulting in partial, distorting, even opaque practices despite stated ideals. These qualities also apply to the question of access: although there exist rather clear-cut guidelines (Human Rights Committee 2018), the reality of $\mathrm{UN}$ operations is more intricate. Just as it is impossible to deduce the detailed microstructure of ice from outside appearances, passages to inclusion within the inner contours of the UN bureaucratic apparatus are equally hidden. Importantly, however, opaque transparency accompanied by fuzzy logic may appeal to many UN insiders as essential tools to protect the fragile human rights apparatus and boost its impact.

\footnotetext{
${ }^{3}$ For introduction into the UN treaty body framework and human rights monitoring as well as their domestic applications, see Keller \& Ulfstein 2012; Bassiouni \& Schabas 2011; Crawford 2010; Simmons 2009; Bayefski 2000.
} 
At the heart of this article is the ethnographer's attempt to transform from an inconspicuous and detached scholar - a nobody - into a somebody whose existence was not only noted by the insiders of this high profile UN expert body via mundane small talk, but with whom they occasionally chose to talk and who even held fleeting roles of relevance in the proceedings that unfolded. The central figure in these efforts becomes the conspicuous ethnographer, a tactical subject who "'to think and act tactically is an indication that one has cultivated a meta-pragmatic level of perceptivity, of the social field in which one is located." (Kyriakides 2018, PLEASE INSERT PAGE, building on Wagner 1967; Wagner 2010; Bourdieu 1977; Bailey 1983). This mastery translated into an opportunistic embrace of a pre-existent category in UN bureaucracy, namely, that of the intern (Billaud 2014; Cowan \& Billaud 2017; Sapignoli 2017), which provided a powerful engaged position from which to test the border of inclusion and exclusion as an ethnographer.

Via ethnographic glimpses from the Palais Wilson, this article details three techniques mobilized when attempting to gain access to closed sessions - name-dropping, 'playing blonde' and opportunism - all connected to a broader, underlying, tactical matrix labelled exaggerated transparency: a tool for establishing liaisons and providing legitimacy for the research project among informants. This article examines instances of both success and failure, reflecting the amorphous border of inclusion and exclusion within the UN bureaucratic apparatus and recalling Anna Tsing's reminder of the importance of treating seeming failures as openings to new insights and analysis (Tsing 2015). The figure of the conspicuous ethnographer is a departure from familiar notions of infiltration and camouflage presented in disciplinary handbooks, but necessary: the interim nature of most UN monitoring mechanisms and the internal rotation of staff mean that people are continually on the move and likely to differ from one fieldwork period to the next. Thus, the real guarantor of continued access are the relations that the ethnographer is able to establish within the apparatus through conspicuous presence, instead of direct personal relations.

This article builds on a flourishing anthropology of international organizations, human rights and international bureaucracy (Müller 2013; Niezen \& Sapignoli 2017; Dembour 2006, Kelly 2011, Schulte-Tenckhoff 2011 \& Khan 2011; Merry 2016; 
Merry, Davis \& Kingsbury 2015; Allen 2013, Abélès 2011 et al). This research has done a great deal to increase our understanding of the operations and inner dynamics of the field, including its reliance on the techniques of audit (Cowan 2014, Cowan \& Billaud 2017, Shore \& Wright 2015); infatuation with quantified data (Merry 2016); and elision of the 'personal' (Billaud 2014). We have also seen collective questioning of how we should characterize the ethnography of such field sites: should it be framed as 'multi-sited', extended, non-local, 'deterritorialized' (Rabinow et al. 2008; Andersson 2014; Feldman 2011, Marcus 1995, Holmes \& Marcus 2005) or even 'parasitic' (Deeb and Marcus 2011)? These observations have given rise to calls for new methodologies (Michel-Rolph Trouillot 2001, 135, Feldman 2011, 378-9), embodied, for example, in Annelise Riles' work on networks and collateral knowledge (Riles 2001, 2011).

Yet we have seen less discussion of how access and engagement are reconfigured in such settings, or analysis of what this might reveal of the inner functioning, dynamics and 'impact' of such apparatuses. This article engages with these issues on the basis of the writer's ongoing study of UN human rights monitoring since 2009 which, in addition to participant observation, has included interviews with Committee members, UN civil servants, NGO delegates and state representatives. This data has been anchored around detailed examination of one specific report: the $6^{\text {th }}$ state report of Finland which was processed in the Human Rights Committee's July session of 2013. In 2013 I followed the Human Rights Committee's three annual sessions, which jointly lasted circa 15 weeks.

I first visited the Palais Wilson in 2007 when examining how conceptions of education, expertise and human rights knowledge were embodied in the activities of a network of Nordic human rights experts (Halme-Tuomisaari 2013a; 2010). In 2010 I continued my inquiry via a study of how human rights documents were compiled at the Finnish Ministry of Foreign Affairs (Halme-Tuomisaari 2012). Simultaneously, I was exploring its history (Halme-Tuomisaari \& Slotte 2015), a project that included archival research into the drafting of the Universal Declaration of Human Rights in the 1940s (Halme-Tuomisaari 2015). Thus, when I commenced my fieldwork at the Palais Wilson I was both a seasoned human rights researcher, and a newcomer in the 
Committee sessions - a duality that proved essential in the tactical manoeuvring for access.

'Do you think I could - if it isn't too forward of me...'

It is the end of yet another session in the main conference room of the Palais Wilson, located on the spacious main floor. The session has, once again, discussed an issue of paramount importance: the realisation of obligations listed in the International Covenant on Civil and Political Rights (ICCPR) in one of the Covenant's member states. These sessions form the core of the monitoring mechanism's operations: the 'constructive dialogue' that takes place between representatives of state parties and international Human Rights Committee experts from the most 'lawlike' and authoritarian of all the ten UN treaty bodies that monitor how states comply with their covenant bound obligations. ${ }^{4}$

These sessions - attended, in theory at least, by ample civil society representatives (Halme-Tuomisaari 2017) - are characterised by a charged atmosphere (and some inevitable boredom (Billaud \& Halme-Tuomisaari 2013). The atmosphere is intensified by the immense preparatory work in UN offices in Geneva and diverse national contexts around the world as well as all the practical hassle that joining them has required, namely the coordination of work, schedules and, of course, travel to Geneva. The release of tension is palpable as a session ends and people rush out of the room: NGO delegates discuss whether the issues they had laboured on to bring to the attention of Committee members were, in fact, raised, and whether state representatives have addressed or side-lined them; calls home are made; perhaps press releases are drafted - and the Committee members need their coffee break too!

I am feeling the tension myself, but for very different reasons. Will this be the moment when I am finally able to strike up a conversation with one of the Committee members? Or perhaps a member of the UN Secretariat before they rush off to prepare for the next session? An NGO activist, even a member of a state delegation? With my

\footnotetext{
${ }^{4}$ For scholarship on UN treaty bodies and human rights monitoring, see, for example, Megret 2012; Bayefsky 2000; Kamminga and Scheinin 2009; Crawford 2010; Gearty and Douzinas 2012; Cassese 2012; Bassiouni and Schabas 2011; Simmons 2009.
} 
'UN expression' - an earnest portrayal of interest and excitement - plastered on my face, exhausting my jaw muscles from so much wear, I linger at the doorway. Most of the Committee members pass me by, either indifferent to my presence or acknowledging me with a faint nod. By now most of them recognise me - I have spent a fair amount of time in the sessions, and the number of people who consistently attend is not that large. Yet most have neither the slightest idea as to who I may be, nor any interest in finding out. They spend their days at the sessions, their nights in preparation, mornings in breakfast meetings, lunches at different hearings or informal meetings and evenings in dinners and receptions. There is simply no room for random chats with the anthropologist. Aware of this, I attempt once again something else: I share a random comment to someone passing me by, attempting to fall naturally into the flow of their movement so as to find an entry point for continuing our discussion during the walk to the located at the other end of the corridor.

It feels as if I am fishing, hoping for a few gentle nibbles that will allow me to get them hooked. I try using personal detail as a lure, mentioning, perhaps, that I have once again barely slept as our one-year-old has kept me up; I experiment by volunteering something of shared expertise, commenting on the skill of the state delegation in responding to the issues highlighted by the Committee, or the size of the audience compared to the previous state report. I play with being 'blonde', asking why conference service staff dash in and out of the room with so many papers in their hands. Usually, I get something back in return, that is, if I have succeeded in judging my interlocutor correctly; fortunately, it is considered rude not to engage in small talk with the person next in line at the UN cafeteria, even if you are a member of a highprofile Committee.

Yet, realistically, I can continue with meaningless chit-chat for only so long before coming across as the lone village idiot. Before my moment expires, I bring out the main bait: under the pretence of something or other I weave into the conversation that I am an anthropologist conducting a study of UN human rights monitoring, and that I am a long-time student of one of the most famous figures in (critical) international law, Professor Martti Koskenniemi (Koskenniemi 2005, 2004). Usually, this does the trick. As if Sesam had opened his gates, I watch my interlocutor's expression changing from indifference to keen interest. I have been transformed from a nobody- 
a random, detached observer of irrelevance, a 'stranger, an alien, possibly an enemy' who 'in an important sense [does not] exist' until I 'reveal my networks' (Shipton 2003:67; Cohen and Odhiambo 1989:27) - into a somebody who not only is doing something potentially worthwhile, but who via her disciplinary relations holds distinct liaisons to my interlocutors. ${ }^{5}$ I have succeeded in creating a sticky surface: a subtle thawing of the smooth surface of the iceberg without which the exchange would merely slide by, irrelevant. Instead, our exchange has now transformed into a space of shared reflection, potentially evolving toward multifaceted personal reflections including considerations of success, failure, triumph, fatigue and indifference.

In such moments it is usually best not to dwell on too much detail - such as that in reality I am a senior researcher and a mother of two, for instance - and instead allow people to slot me into a commonly assigned category: an intern who is probably a $\mathrm{PhD}$ candidate. I usually mention my actual scholarly status in passing, yet in continued interaction I embrace the assigned categorization, pairing it up with a performance of a distinct, exaggerated habitus: 'blondness'. With this I refer not to the literal state of having blonde hair - which, ironically, I have - but to the figurative elements commonly associated with 'blondeness': uninformed naivety, somewhat childlike dependence, non-threatening benevolence - a portrayal that is highly familiar from the world of cinema, for example.

Consciously, I embrace the role of eager student - a pre-existent and well-established slot in UN bureaucracy (Halme-Tuomisaari 2010) - evading the role of expert that I assume confidently and credibly in other contexts: for example, when teaching human rights issues at universities. Concomitantly, and with intention, I calibrate a power hierarchy between my interlocutors and myself, emphasizing the reality of my interlocutors' superior professional status compared to my own position in the context. I am actively complicit in creating a fieldwork situation of 'studying up' (Nader 1972; Nader 2011).

\footnotetext{
${ }^{5}$ Cohen and Odhiambo add 'and importantly, until this network has been verified by my interrogators'; yet in the international human rights field this is seldom the case as merely mentioning names may suffice to establish connections due to the intricate and vast nature of international human rights bureaucracies.
} 
What are the gender dimensions and attendant ramifications of this role play? These questions have acquired additional momentum from the \#MeToo campaign that started in autumn 2017 and has since reached the UN, albeit in restricted ways (Kirkpatrick 2017; Guardian 2018; Rickard-Martin 2018). As in all contexts, gender asymmetry is present, yet its impact is subdued compared to the distraught power dynamics of \#MeToo. My key interlocutors were fairly equally divided between the two genders, although the profile of experts on the Human Rights Committee itself is predominantly male - female Committee members consistently comprise only about one third of the 18 members - echoing broader findings on the gendered expertise of human rights (Halme-Tuomisaari 2010). Yet the UN secretariat and conference services have more female personnel even if the Committee's gender disparity is reproduced in top positions. The gender of NGO delegates is also more mixed, as was the case with interns. The state delegation of Finland that I followed closely was entirely female, apart from the male head. Thus it would be erroneous to conclude that the access that I eventually gained was somehow embedded in a sexist and patriarchal culture that some claim to characterize UN operations. Rather, my access was dependent on interlocutors of both gender - and I would argue further that performing 'blondness' would probably also have worked for a male anthropologist.

It is difficult to say how convincing I am in my role-play. Yet my embrace of 'blonde' habitus succeeds in engaging my interlocutors to a sufficient degree to allow our interactions to evolve. Simultaneously, I make my role-play explicit via exaggerated transparency over the content of my research, offering to share my research proposal with my UN interlocutors and telling them exactly what, and how, I am studying via my participant observation. I also volunteer to share draft articles of my work. Whether my interlocutors really grasp what all this means remains uncertain. Despite shared terrain in terms of scholarly and professional background (Halme-Tuomisaari 2010), there is one essential difference between me and my interlocutors: we approach human rights from the opposite sides of 'ideology'. For my interlocutors it is evident that human rights are unambiguously good entities, integral tools for world improvement. While they recognise that improvement is slow, they never challenge whether it is actually happening; for me, on the other hand, it does not appear certain (Halme-Tuomisaari 2010:19). Still, via my exaggerated transparency, my tactical 
role-play is exposed, shared, perhaps even laughed about - 'we are your tribe' is a common-enough joke in such discussions.

Thus the conspicuous ethnographer became a subjectivity that was 'aware of itself' (Wagner 2010, 21), creating a shared reflective space beyond deceit due to my interlocutors' analytical sophistication and their upper hand in our power relations. Simultaneously this space was subject to negotiation and bargaining, making my liaisons dangerous. Playing this game required keen tactical awareness of the extent to which it was prudent and necessary to make my relations visible (Feldman 2011) and when it was more advantageous to 'contain within the body in order to generate potential' (Kyriakides 2018, PLEASE INSERT PAGE).

Yet playing with this risk was essential as it embodied the only hope of gaining access and transitioning from an inconspicuous, detached observer into a keenly engaged participant sharing the tensions, anticipations, excitement - and even boredom - of Human Rights Committee sessions. Eventually my aspirations were met and I was able to move from the public sessions of the Committee to closed NGO hearings, to gain glimpses of background preparations by individual Committee members, draft work engaged in by state representatives and preparations for NGOs' ancillary reports. I was also able to join instances of NGO lobbying during the Committee's sessions alongside NGO delegations; I was becoming an insider.

Getting in - only to be excluded again

The transformation of my status is concretised by the degree of access I enjoyed at the three sessions of the Human Rights Committee I followed (Halme-Tuomisaari 2013b). In the first session I had no pre-existing connections inside the Committee, and thus nobody at the Committee or the UN Secretariat to take me under their wing. This, I soon discovered, separated me from virtually everyone else who stayed in Geneva and frequented the Palais Wilson for the entire duration of the Committee's five-week session; by all accounts, I was the only genuine outsider perennially present. Other observers - such as journalists, state representatives and NGO delegates who commonly flew in and out of Geneva for a matter of days - usually only visited the sessions a few times, often in regard to the processing of a particular 
state's report. Those who stayed put were usually in some manner connected either to the UN secretariat or the Committee.

For the first session I had secured an observer badge, which entitled me to follow sessions open to the general public, most importantly, the constructive dialogue that took place in the large conference room between Committee members and state delegates (Halme-Tuomisaari 2013a). In terms of fieldwork this meant that I started to hang around the Palais Wilson from morning until evening, frequenting the cafeteria during breaks or lingering in the hallways when the cafeteria was closed; this was straightforward and rewarding in terms of data. Yet it was evident that a more nuanced comprehension of the Committee's work required greater access - which, in turn, posed a real challenge. Gradually, with ample lingering in doorways, my situation improved. I was able to initiate a series of lunch and coffee meetings with Committee members, NGO delegates and the occasional member of the UN Secretariat. Eventually I stayed in touch with one Committee member between sessions, performing small assistant tasks as he prepared for the second session that I attended.

Integral to my eventually increasing access was my continued association, which had commenced at the very beginning of the first session, with the category of intern (Billaud 2014; Cowan and Billaud 2017; Sapignoli 2017). This category consisted of undergraduate or $\mathrm{PhD}$ students who stayed in Geneva for the duration of the Committee's sessions as interns of specific Committee members, who in turn were usually university professors in their home countries. My association with this category not only offered the social benefit of having company for lunch-breaks, but also facilitated opportunistic navigation of the border of inclusion and exclusion. This began with innocent inquiries as to why certain sessions were closed to observers while the interns were allowed access. It was via such discussions that I learned that not even the interns themselves were always sure whether they were formally permitted to attend a session or not. They usually followed subtle clues from 'their' Committee member indicating whether it was appropriate for them to be present or not. 
Usually, as the weeks wore on, Committee members lowered their guard, and some of the interns became bolder in experimenting; they would simply show up at a meeting, and if they were not told to leave, they would treat this as permission to stay. I soon started to follow cue: where the interns went, I went too. By this time - because of the exaggerated transparency I brought to my research - everyone in positions of responsibility within the Committee knew that I was an anthropologist doing an ethnographic study of the sessions. Subsequently I started to treat this shared knowledge as my ultimate badge of inclusion; if those responsible for managing the border between inclusion and exclusion in the sessions did not actively exclude me, I took that as a sign that I was allowed access. Probably not everyone remembered that I was not an actual intern, yet nobody ever questioned whether I had the right badge to attend or not. In fact, as one part of my experiment, I never wore my badge - the plastic artefact with my name and affiliation printed on it - despite being told always to do so by the security guards upon entering the Palais. Nobody ever asked to see it either. Thus I learned that at this point the real access badge was, in fact, a confident demeanour and a casual nod and a slight smile when encountering people in the hallway, a significant insight onto the inner dynamics of the UN apparatus. I also learned of the micro-dynamics of power - here embodied in overseeing who were bestowed access - that strategically placed insiders were able to mobilize inside the sessions, as well as the fuzzy logic that hovered in the background.

In fact, in all the weeks that I spent at the Palais, only once did someone question whether I had the required access to participate in a given session and, as I was in the company of interns, this question was not directed solely at me. Eventually we all succeeded in defending our entitlement to stay by highlighting our association with individual Committee members, thereby capitalising on our knowledge of the Committee's inner dynamics. Its members - who are (ideally) renown international experts on human rights matters, commonly either university professors or diplomats - are the 'stars' of the sessions, whereas many members of the UN Conference Services attending to practical matters may be junior UN officials with temporary contracts. Thus, the interns were able on occasion to tactically employ this discrepancy of professional rank between UN staff and the interns' patrons, boldly and opportunistically pushing the boundary of inclusion in their favour. 
Despite merely having observer status, by the end of the first session I was considered sufficiently an insider to be allowed to sit in on the lunchtime NGO briefings that were closed to representatives of the states. By the second session I was able to sit in on the occasional closed Committee session, which were off-limits to NGO representatives. I had direct contacts with numerous Committee members, and even acted as an occasional NGO lobbyist. Yet it was the third session that shifted the boundary of inclusion even further. As the second session was about to end I asked a Committee member if he would take me on as an informal intern for the third session of the year - to which he agreed. This meant that when I returned in the fall I had access to all the Committee's sessions, including those closed to general observers. Importantly this also provided access to restricted documents inside the sessions, on which the Committee member for whom I informally interned occasionally asked for my views. This access can be interpreted as the outcome of established liaisons which had transformed me from 'a nobody into somebody', simultaneously giving me occasional roles of relevance. Relations were central to this transformation: namely, my affiliation with a known authority in the field of human rights, which I had tactically shared earlier. In the course of my prolonged presence at the Committee's sessions these relations led first to liaisons and a sticky surface, eventually becoming, at least temporarily, direct social connections. It was this combination of factors rather than any formal permit or badge - that facilitated access.

Yet despite all this, my access remained far from unrestricted. I continued to experience surprising moments of exclusion even while sitting inside closed sessions with full entitlement. This is illustrated by an incident involving a restricted document with which the Committee was dealing, unusually handed out as a printed copy during the session and not distributed electronically as usual, probably due to the document's late arrival. As a civil servant working at the UN Secretariat distributed copies around the conference room she casually passed me by, despite knowing who I was from earlier contact. I asked her if I too could have a copy, to which she responded that I would need to get one directly from the Committee member for whom I was interning since he was responsible for my access to the session in question. As we were in mid-session it did not feel appropriate to disturb the Committee member, and hence I never got to inspect the document in question. This moment illustrates exactly how inside the UN apparatus access never becomes 
something that one simply has, but rather remains elusive and volatile, subject to negotiation, temporal restrictions and surprise.

Further, my newly-found access as a whole was both temporary and vicarious: my informal internship lasted only for that single full session of the Human Rights Committee, and as soon as it was over I was an outsider again, with no access even to the Palais Wilson without renewed accreditation - just like everyone else who had been given access on the inside of this awesome bureaucratic apparatus for this particular session, save for the few permanent staff members of the UN Secretariat. As my internship was merely the result of a casual verbal agreement, I also had no paperwork to testify to my internship status had it been requested at any stage.

Ironically, the same applied to a written research permit for my entire project. I had once discussed the matter with the Chairman of the Committee, a highly influential insider in UN human rights circles. He considered it futile to forward a written request as '(t)he Committee has other matters to attend to'. Following the sessions I could only agree. As fate would have it, quite soon thereafter the Chairman passed away, quite unexpectedly, and with him died the only verbal record that such an exchange ever took place - not that he would necessarily have remembered it anyway. All this testifies, once again, to how fuzzy and contingent the borders of inclusion and exclusion are, and how temporary even the most cautious plans to solidify access may become within the UN bureaucratic apparatus. Just like ice thaws, perhaps melts a bit, then freezes again, subsequently forever sealing the small cracks and toeholds that once existed on its surface, so do the passages of access for an anthropologist studying UN bureaucracies. They open only to close again - quite unexpectedly and without a trace or explanation.

\section{Conclusion}

This paper has discussed a fieldworker's aspirations for access to a controlled forum in an attempt to contribute toward ongoing debates on global ethnographies via the lens of the 'tactical subject', embodied in the persona of the conspicuous ethnographer. It has illustrated how even in a seemingly transparent context, such as the UN's human rights monitoring apparatus, access remains subject to negotiation, 
bargaining and an opportunistic seizing of moments. Arrangements for, and moments of, access are volatile and temporary, possibly even leading to the closing of previously accessible paths after the fact. These ethnographic insights summarise a key element of the UN bureaucratic apparatus, the 'fuzzy logic' that accompanies seemingly clear guidelines for access and structures of operation.

This fuzziness is in part caused by the infinite rotation of people. As most UN personnel hold office for a fixed period, there are only a few people who are genuine insiders in any given monitoring mechanism or expert body; rather, most will always be partially insiders, partially outsiders. The ceaseless movement of people is intensified by the nature of most UN monitoring mechanisms, which convene periodically, continue with preparatory work and follow-up before and after concrete sessions, and change frequently in their composition. The members of UN monitoring mechanisms also change quite often due to the fixed nature of appointments. This casts the inner dynamic of the UN apparatus in a highly distinct light: instead of direct social contacts, many people - not just the ethnographer - will be connected to the apparatus via mediated relations.

These findings hold broader relevance for the functioning of UN bureaucracies. One illustration relates to how the expert members of UN treaty bodies are selected: whereas the Human Rights Committee, for example, convenes only in Geneva, its expert members are chosen by state parties at the UN headquarters in New York, while the UN personnel working with a given treaty body will have no say in a candidate's suitability or skills for the position. Sometimes the selection process yields unexpected outcomes, as in 2014 when the Committee found itself in the position of having $1 / 3$ of its members replaced overnight, including seasoned insiders who were considered practical fixtures by the Geneva office. This was an outcome that had a dramatic impact both on inner dynamics and the operations of the Committee's workload as the Secretariat had to deal with a great number of newcomers who were not familiar with earlier working methods.

Whereas this outcome might appear troubling or even shocking to the external observer, to the insider it is less noteworthy; this is how UN personnel selections always go, one seasoned insider noted, adding that this was also the reason why many 
insiders were noticeably disinterested in such selection processes. 'No matter how things appear beforehand and who appear to be the top candidates, one will never know what the outcome will be before things are finalized.' Long-term insiders are accustomed to the fuzzy logic of the UN, and know how to manoeuvre within it. Inevitably the fuzzy logic provides opportunistic moments for seasoned insiders to exert their influence, just as this article has detailed vis-à-vis the conspicuous ethnographer; newcomers will be reliant on their help, and hence under their influence, while they are initiated into their roles.

One can even trace the fuzzy logic of the UN apparatus more broadly behind UN operations and their impact, including treaty bodies. Whereas the mandate of human rights treaty bodies is based on covenant provisions (ICCPR 2017), ${ }^{6}$ many elements of what the treaty bodies actually do, and how they do it, have been determined by the Committees and the UN Secretariat over the past decades. Seasoned insiders are well aware of this reality, as became evident during sessions discussing the strengthening of the UN treaty body framework, which included high profile UN insiders. In a discussion on the wording of the document to be submitted to the UN Office of the High Commissioner for Human Rights as a platform for action, it was asked during a roundtable conversation whether it was not unwise to attempt formulations that were too specific. After all, it was noted, many elements in the operations of treaty bodies were at the discretion of the treaty bodies; matters would only be complicated if these issues were brought to the attention of the relevant states who could then attempt to curtail or manipulate them. Thus the argument was explicitly one against transparency; indeed, it favoured fuzzy logic as the most effective means for ensuring the undisturbed work of treaty bodies, and their greater impact in and on the world to promote human rights ideals.

\footnotetext{
${ }^{6}$ Article 36 of the ICCPR states: "The Secretary-General of the United Nations shall provide the necessary staff and facilities for the effective performance of the functions of the Committee under the present Covenant." But Article 39, par 2 clarifies that "The Committee shall establish its own rules of procedure, but these rules shall provide, inter alia, that (a) Twelve members shall constitute a quorum;
}

(b) Decisions of the Committee shall be made by a majority vote of the members present." 
This insight concretizes, in turn, why most scholarly accounts - particularly those promoted by international lawyers or international relations scholars and based on textual analysis of the wording of distinct UN documents - are set to fail in providing meaningful information when analysed separately from their broader context, a finding that to certain extent also applies to the ethnography of documents. Rather, this paper argues, within UN human rights bureaucracies the real insights or mechanisms of impact are rarely available for discovery via textual sources, via focussing on the issues that they address, and are, conversely, embedded broader dynamics and logics and even in desires to make certain things opaque or even invisible.

One angle from which to approach these tendencies links up with the essential fragility that on closer examination characterizes the work of the UN Human Rights Committee and the UN human rights monitoring framework generally: they may be decades old, and accompanied by highly respected expert bodies, yet their continued existence and tangible impact, as well as their sustained legitimacy, are highly delicate matters. This sense of delicacy is intensified by the wide-ranging threats that the post-world-war international order currently faces, whether embodied in the threat of numerous African states' withdrawing from the International Criminal Court (Trigt 2016, BBC 2017); the possible abolishing of the UK Human Rights Act following Brexit (Gearty 2016); President Trump's proclamation that the US will withdraw from the Paris Climate Agreement (The Guardian 2017); or the proliferation of powerful bi-lateral covenants such as the planned Trans-Atlantic Trade and Investment Partnership (TTIP) to subvert state regulatory powers and those of international organizations (TTIP 2017). In June 2018 many of these fears were confirmed as the US announced its withdrawal from the UN Human Rights Council (UN Human Rights Council 2018), thus ending a brief historical moment of universal human rights monitoring.

The sense of looming threat - paired with localised experiences of disillusionment over the international human rights regime, as eloquently described, for example, by Lori Allen in regard to Palestine (Allen 2013) - has inspired some to call this the 'endtimes of human rights' (Hopgood 2013). Understandably this awakens concern among insiders of UN human rights bureaucracies and 'pro-human rights scholars' - 
two groups that are often synonymous with one another - which may extend to scholarship that is either critical or overtly transparent and thus perceived to compromise the continued sustenance of this fragile system as well as the role of human rights worldwide. Here the fuzzy logic of the UN bureaucratic apparatus may serve an instrumental role in providing additional protection for the system, including the potential damaging consequences of overt transparency.

To conclude, these observations concretize the constraints of empirical observation that apply both to conducting ethnography at the Palais Wilson and any other incarnation of the UN human rights apparatus; just as with an iceberg, parts of this apparatus will be visible, many other parts invisible: a fundamental element of such global processes. The task of the ethnographer is thus not to fill in the blanks via attempts at comprehensive empirical coverage, as such efforts are doomed to fail. Rather, the task becomes one of shifting one's analytical inclination toward encompassing these gaps as tangibly real elements in the very constitution of the global apparatus.

Simultaneously, these observations give rise to one final question: is it tactical of me to share all that this paper entails, to flirt so openly with transparency and thus potentially compromise the access that I have secured as a conspicuous ethnographer within the fuzzy logic of the UN human rights apparatus? Would it be wiser - in the interest of continued access to UN bodies - to 'contain them within the body', thus maximizing the potential that this knowledge holds for future fieldwork? This is something that only time will tell. Just as ice reacts to sunlight, freezing temperatures and thawing, so do the micro-dynamics of UN bureaucracy continually re-adjust to personnel changes, budget fluctuations and new procedures. To the newcomer the border of inclusion may begin and end with the securing of a badge to enter a UN building. Yet, the seasoned insider knows better, and also knows that one can never fully predict whether access today means access tomorrow. Thus the question of continued access for the conspicuous ethnographer will also remain uncertain.

Bibliography 
Abélès, Marc (2011) Des anthropologues à l'OMC: Scènes de la gouvernance mondiale, CNRS Editions, Paris.

Allen, Lori (2013) The Rise and Fall of Human Rights Cynicism and Politics in Occupied Palestine. University of Stanford Press, Stanford.

Andersson, Ruben (2014) Illegality, Inc.: Clandestine Migration and the Business of Bordering Europe. University of California Press, Oakland.

Bailey, F. G. (1983) The Tactical Uses of Passion: An Essay on Power, Reason, and Reality. Cornell University Press, Ithaca.

Bassiouni, M. Cherif, and William A. Schabas (eds.) (2011) New Challenges for the UN Human Rights Machinery: What Future for the UN Treaty Body System and the Human Rights Council Procedures? Intersentia.

Bayefsky, Anne F. (2000) The UN Human Rights Treaty System in the 21st Century. Kluwer Law International, Leiden.

BBC (2017) African Union backs mass withdrawal from ICC, 1 February, 2017, http://www.bbc.com/news/world-africa-38826073

Billaud, Julie (2014) 'Keepers of the "Truth": Producing "Transparent" Documents for the Universal Periodic Review. In Assessing the Universal Periodic Review (eds. Charlesworth \& Larkin). Cambridge University Press, Cambridge, 63-84.

Billaud, Julie, and Miia Halme-Tuomisaari (2013) Toward the Anthropology of Boredom (REDUX). http://allegralaboratory.net/toward-the-anthropology-ofboredom-redux/. 23.11.2013.

Bourdieu, Pierre (1990) In other words: Essays toward a reflexive sociology. Stanford University Press, Stanford.

(1977) Outline of a theory of practice. Cambridge University Press, Cambridge. 
Cohen, David William, and E. S. Atieno Odhiambo (1989) Siaya: The Historical Anthropology of an African Landscape. Ohio University Press, London.

Cowan, Jane and Julie Billaud (2017) 'The "Public" Character of the Universal Periodic Review: Contested Concept and Methodological Challenge' in Palaces of Hope (eds. Niezen \& Sapignoli). Cambridge University Press, Cambridge, Pp. 106126.

Cowan, Jane ( 2014) 'The Universal Periodic Review as Public Audit Ritual: An Anthropological Perspective on Emerging Practices in the Global Governance of Human Rights'. In Human Rights and the Universal Periodic Review (eds.

Charlesworth \& Larkin), Cambridge University Press, Cambridge, Pp. 42-62.

Crawford, James (2010) The Future of UN Human Rights Treaty Monitoring. Cambridge University Press, Cambridge.

Deeb, H., and George E Marcus (2011) 'In the Green Room: An Experiment in Ethnographic Method at the WTO'. PoLAR: Political and Legal Anthropology Review 34: 51-76.

Dembour, Marie-Bénédicte (2006) Who Believes in Human Rights? Reflections on the European Convention. Cambridge University Press, Cambridge.

Feldman, Gregory (2011) 'If Ethnography Is More than Participant-Observation, Then Relations Are More than Connections: The Case for Nonlocal Ethnography in a World of Apparatuses'. Anthropological Theory 11(4), 375-395.

Foucault, Michel (1977) 'The Confessions of the Flesh', in Power/Knowledge Selected Interviews and Other Writings (Ed Colin Gordon), 1980, Pantheon Books, New York, 194-228. 
Friedland, Roger (2009) 'The Endless Fields of Pierre Bourdieu'. Organization 16(6), $1-31$.

Gearty, Conor (2016) The Human Rights Act Should Not Be Repealed, Sept 27, 2016 https://ukconstitutionallaw.org/2016/09/17/conor-gearty-the-human-rights-act-shouldnot-be-repealed/

The Guardian 2017. Donald Trump confirms US will quit Paris climate agreement, 1.6.2017, https://www.theguardian.com/environment/2017/jun/01/donald-trumpconfirms-us-will-quit-paris-climate-deal

The Guardian (2018) Sexual harassment and assault rife at United Nations, staff claim. 18.1.2018. https://www.theguardian.com/globaldevelopment/2018/jan/18/sexual-assault-and-harassment-rife-at-united-nations-staff$\underline{\text { claim }}$

Halme-Tuomisaari, Miia (2017) Meeting "the World" at the Palais Wilson: Embodied Universalism at the UN Human Rights Committee. In Palaces of Hope (eds. Niezen \& Sapignoli). Cambridge University Press, Cambridge, Pp. 127-151.

(2015 a) 'Revisiting the History of Human Rights: Introduction' (co-authored with Pamela Slotte) in Revisiting the Origins of Human Rights (eds. Slotte \& HalmeTuomisaari). Cambridge University Press, Cambridge, 2015, 1-36.

(2015b) 'Lobbying for Relevance: US Internationalists, French civil libertarians and the UDHR,' in Revisiting the Origins of Human Rights (eds. Slotte \& HalmeTuomisaari), Cambridge University Press, Cambridge, 2015, 330-361.

(2013a) 'Contested Representation: Exploring China's State Report,' Journal of Legal Anthropology 1/2013 No. 3, 333-359.

(2013b) Fieldnote: Arriving at the UN. Allegra: A Virtual Lab of Legal Anthropology. http://allegralaboratory.net/fieldnote-arriving-at-the-un/. 
(2012) 'The State Is One: Examining What "Fact" Means in the Compilation of a Human Rights Report'. Suomen Antropologi: Journal of the Finnish Anthropological Society(1): 22-30.

(2010) Human Rights in Action: Learning Expert Knowledge. Brill Academic Pub.

Holmes, Douglas and George Marcus (2005) 'Cultures of Expertise and the Management of Globalization: Toward the Re-functioning of Ethnography,' in Global Assemblages (Aihwa Ong and Stephen J. Collier, eds). Oxford: Blackwell, pp. 23552.

Hopgood, Stephen (2013) The Endtimes of Human Rights. Cornell University Press, Ithaca.

Human Rights Committee (2018): Accreditations.

https://www.ohchr.org/EN/HRBodies/CCPR/Pages/Accreditation.aspx Site accessed on 5 June 2018.

ICCPR 2017. International Covenant on Civil and Political Rights. http://www.ohchr.org/EN/ProfessionalInterest/Pages/CCPR.aspx

Keller, Helen \& Ulfstein, Geir (eds) (2012): UN Human Rights Treaty Bodies: Law and Legitimacy. Cambridge University Press, Cambridge.

Kelly, Tobias (2011) This Side of Silence: Human Rights, Torture, and the Recognition of Cruelty. University of Pennsylvania Press, Philadelphia.

Kirkpatrick, Laura (2017) Sexual Harassment at the UN Is Alive and Persistent, 22.12.2017, http://www.passblue.com/2017/12/22/sexual-harassment-at-the-un-isalive-and-persistent/

Koskenniemi, Martti (2004) The Gentle Civilizer of Nations: The Rise and Fall of International Law 1870-1960. Cambridge University Press, Cambridge. 
(2005) From Apology to Utopia: The Structure of International Legal Argument. Cambridge University Press.

Marcus, George (1995) 'Ethnography In/of the World System: The Emergence of Multi-Sited Ethnography'. Annual Review of Anthropology 24: 95-117.

Merry, Sally Engle (2016) The Seductions of Quantification: Measuring Human Rights, Gender Violence, and Sex Trafficking. University of Chicago Press, Chicago.

Merry, Sally Engle, Kevin E Davis, and Benedict Kingsbury, eds. (2015) The Quiet Power of Indicators: Measuring Governance, Corruption, and Rule of Law.

Cambridge University Press, Cambridge.

Müller, Birgit (2013) The Gloss of Harmony: The Politics of Policy Making in Multilateral Organisations. PlutoPress, London.

Nader, Laura (1972) 'Up the Anthropologist-Perspectives Gained from Studying Up'. In Reinventing Anthropology (Dell Hymes, ed). Pantheon books, New York, Pp. 284-311.

(2011) 'Ethnography as Theory'. HAU: Journal of Ethnographic Theory 1(1): 211219.

Niezen, Ronald, and Maria Sapignoli (Eds) (2017) Palaces of Hope: The Anthropology of Global Organizations. Cambridge University Press, Cambridge.

Rabinow, Paul (2003): Anthropos today: Reflections on modern equipment. Princeton University Press, Princeton.

Rabinow, Paul, George E Marcus, James D Faubion, and Rees (2008) Designs for an Anthropology of the Contemporary. Duke University Press, Durham. 
Ricard Martin, Loraine (2018) The UN and \#MeToo: All Forms of Abuse Must End

Now. 9.5.2018. http://www.passblue.com/2018/05/09/the-un-and-metoo-the-saga-ofabuse-must-end-once-and-for-all/

Riles, Annelise (2011) Collateral Knowledge: Legal Reasoning in the Global Financial Markets. University of Chicago Press, London.

(2001) Network Inside Out. The University of Michigan Press, Ann Arbor.

Sapignoli, Maria (2017) 'A Kaleidoscopic Institutional Form: Expertise and Transformation in the UN Permanent Forum on Indigenous Issues'. In Palaces of Hope (eds. Niezen \& Sapignoli). Cambridge University Press, Cambridge, Pp. 78105.

Sarfaty, Galit (2012) Values in Translation: Human rights and the culture of the World Bank. Stanford University Press, Stanford.

Schulte-Tenckhoff, Isabelle, and Adil Hasan Khan

2011 The Permanent Quest for a Mandate: Assessing the UN Permanent Forum on Indigenous Issues. Griffith Law Review 20(3): 673.

Shipton, Parker (2003) 'Legalism and Loyalism: European, African, and Human "Rights."' In At the Risk of Being Heard Identity, Indigenous Rights, and Postcolonial States (eds. Dean \& Levi). University of Michigan Press, Michigan, Pp. 45-79.

Shore, Cris \& Sue Wright (2015) 'Audit Culture Revisited: Rankings, Ratings, and the Reassembling of Society.' Current Anthropology 56(3).

Simmons, Beth A. (2009) Mobilizing for Human Rights: International Law in Domestic Politics. Cambridge University Press, Cambridge.

Trigt, E. Van (2016) Africa and withdrawal from the ICC, 28 October, 2016, https://www.peacepalacelibrary.n1/2016/10/africa-and-icc-withdrawal/ 
Trouillot, Michel-Rolph (2001) 'The Anthropology of the State in the Age of Globalization'. Current Anthropology 42(1), 125-138.

Tsing, Anna Lowenhaupt (2015) The Mushroom at the End of the World: On the Possibility of Life in Capitalist Ruins. Princeton University Press, Princeton.

TTIP 2017. Trans-Atlantic Trade and Investment Partnership, http://ec.europa.eu/trade/policy/in-focus/ttip/ (1.5.2017)

UNOHCHR 2018. Headquarters

https://www.ohchr.org/EN/AboutUs/Pages/Headquarters.aspx

UN Human Rights Council (2018). Remarks by President of the Human Rights Council, on the USA withdrawal from the Council, 20.6.2018.

https://www.ohchr.org/EN/HRBodies/HRC/Pages/NewsDetail.aspx?NewsID=23230 $\underline{\text { LangID }=\mathrm{E}}$

Wagner, Roy (2010) Coyote Anthropology. First Edition. Lincoln Neb.: University of Nebraska Press.

(1967) Curse of Souw: Principles of Daribi Clan Definition and Alliance in New Guinea. University of Chicago Press, Chicago.

Wallerstein, Immanuel (2004) World-Systems Analysis: An Introduction. Duke University Press, Durham. 